\section{The Minerals and Heavy Metals in Cow's Milk from China and Japan}

\author{
Li-Qiang Qin, ${ }^{, a, b}$ Xiao-Ping Wang, ${ }^{a, b}$ \\ Wei Li, ${ }^{a}$ Xing Tong, ${ }^{a}$ and Wei-Jun Tong ${ }^{c}$
}

${ }^{a}$ Department of Nutrition and Food Hygiene, School of Radiation Medicine and Public Health, Medical College of Soochow University, 199 Renai Road, Dushu Lake Higher Education Town, Suzhou Industrial Park, Suzhou, 215123, China, ${ }^{b}$ Jiangsu Provincial Key Laboratory of Radiation Medicine and Protection, 199 Renai Road, Suzhou, 215123, China, and ${ }^{c}$ Department of Epidemiology and Statistics, School of Radiation Medicine and Public Health, Medical College of Soochow University, 199 Renai Road, Suzhou, 215123, China

(Received November 10, 2008; Accepted December 25, 2008)

Cow's milk is an important foodstuff and beneficial to human health. In the present study, commercial milks from China and Japan and raw milk from Inner Mongolia of China were collected. The contents of 18 elements were determined using inductively coupled plasma-optical emission spectrometry (ICP-OES), atomic absorption spectrometry (AAS) and atomic fluorescence spectrometry (AFS). Our analysis showed both Chinese and Japanese milks are rich in macroelements, such as calcium, potassium. However, the milk contents of chromium, manganese and zinc, which belong to microelements, were higher in Chinese commercial milks than in Japanese commercial milks. Heavy metals in food pose potential healthy risk. Although lead and cadmium contents in Chinese milk did not exceed the tolerance limits of Chinese National Standards, they were higher than those in Japanese commercial milks. Based on the high contents of some microelements and heavy metals in Chinese milk, we should innovate the technology and improve quality control for milk process and decrease environmental pollution.

Key words — milk, mineral, heavy metal, lead, cadmium

\footnotetext{
*To whom correspondence should be addressed: Department of Nutrition and Food Hygiene, School of Radiation Medicine and Public Health, Medical College of Soochow University, 199 Renai Road, Dushu Lake Higher Education Town, Suzhou Industrial Park, Suzhou, 215123, China. Tel.: +86-512-65880075; Fax: +86-512-65880050; E-mail: qinliqiang@suda.edu.cn
}

\section{INTRODUCTION}

Milk is a complex, bioactive substance to promote growth and development of the infant mammals. Cow's milk is widely consumed by human children and adults after the age of weaning. Among the nutrients of milk, calcium $(\mathrm{Ca})$ has been well recognized by researchers and the public because of greater stature in children and less osteoporosis in old people. In fact, milk is an ideal source of macroelements, such as $\mathrm{Ca}$, potassium $(\mathrm{K})$, phosphorus $(\mathrm{P})$. Moreover, microelements and even heavy metals can be found in milk. ${ }^{1)}$ Microelements, also called trace elements such as copper $(\mathrm{Cu})$, iron $(\mathrm{Fe})$, selenium $(\mathrm{Se})$ and zinc $(\mathrm{Zn})$ are known to be essential for normal growth. However, heavy metals such as arsenic (As), cadmium (Cd), mercury $(\mathrm{Hg})$ and lead $(\mathrm{Pb})$ have no beneficial effects on human.

Historically, cow's milk was seldom consumed by populations in China (except some minorities) and Japan. After World War II, liquid milk consumption rapidly increased in Japan, with 36.7 liters per capita in 2005. Although per capita consumption of milk in China is as low as 8.8 liters, milk consumption increased $20 \%$ every year. ${ }^{2}$ ) Thus, milk has become and will become important foodstuff consumed in Japan and China. Considering the healthy problem of infant, the minerals, especially heavy metals in breast milk have been intensively researched. ${ }^{3-6)}$ Some studies monitored microelements or heavy metals in cow's milk around polluting areas. ${ }^{7-10)}$ However, the data on minerals in commercial milk are sparse and the comparisons of minerals in cow's milk from different countries are missing. In China and Japan, minerals in commercial milk were found to be published as abstract in local journal. ${ }^{11,12)}$ Since the methods used were not sensitive enough, the re-evaluation of minerals in commercial milk is necessary.

In the present study, we collected commercial milks from China and Japan to determine the mineral contents. Because pasteurization and sterilization processes may influence their contents, ${ }^{13)}$ raw milks collected from Inner Mongolia of China were also analyzed in this study.

\section{MATERIALS AND METHODS}

Instrumentation and Reagents — Vista MPX type inductively coupled plasma-optical emission 
spectrometry (ICP-OES) and Spectr AA 110/220 type atomic absorption spectrometry (AAS) was supplied by Varian Inc. (Palo Alto, CA, U.S.A.). 230 E type atomic fluorescence spectrometry (AFS, Beijing Kechuang Haiguang Instrument Co., Ltd, Chao Yang District, Beijing, China) was used. And microwave Lab Stations (Milestone Inc., Sorisole, Italy) was used in this research.

Unless indicated otherwise, all the reagents used were at least of analytical reagent grade obtained from Sinopharm Chemical Reagent Co. (Shanghai, China). Milk powder GBW10017 was purchased from Institute of Geophysical and Geochemical Exploration, Chinese Academy of Geological Sciences (Langfang, Hebei, China). $1.0 \%(\mathrm{~m} / \mathrm{v}) \mathrm{KBH}_{4}$ solution was prepared by dissolving $\mathrm{KBH}_{4}$ in a $1.0 \%$ $(\mathrm{m} / \mathrm{v}) \mathrm{KOH}$ solution. Deionized water of $18 \mathrm{M} \Omega \cdot \mathrm{cm}$ was used for preparing the solutions.

Sample Collection — Two brands of nationally available commercial milk were purchased from the local supermarkets in Suzhou city, China and Yamanashi prefecture, Japan, respectively. Milks were collected every one and half months from October 2006 to October 2007. Thus, we got 8 samples each milk. These milks were designated as China 1 , China 2, Japan 1 and Japan 2. All of milks were produced from $100 \%$ raw milk and were classified as whole milk. Japan 2 was the milk from Jersey cows and other three were not indicated. Raw milk was collected from Inner Mongolia Prairie of China at May 2007. It was milked by nomads in the morning and stored in $50 \mathrm{ml}$ centrifuge tube. The milks collected from Japan and Inner Mongolia were transferred at $4^{\circ} \mathrm{C}$ by airplane. All samples were stored at $-20^{\circ} \mathrm{C}$ in our laboratory.

Sample Digestion — For the digestion of samples, approximately $10 \mathrm{~g}$ of milk was digested with $10 \mathrm{ml}$ of $\mathrm{HNO}_{3}(65 \%)$ and $2 \mathrm{ml}$ of $\mathrm{H}_{2} \mathrm{O}_{2}(30 \%)$ in acid-prewashed Teflon vessels. After standing overnight, samples were digested using Microwave Lab Stations with the following program: $250 \mathrm{~W}, 1 \mathrm{~min} ; 0 \mathrm{~W}, 1 \mathrm{~min} ; 250 \mathrm{~W}, 6 \mathrm{~min} ; 400 \mathrm{~W}$, $5 \mathrm{~min} ; 600 \mathrm{~W}, 5 \mathrm{~min}$. After sufficient cooling, samples were moved to Teflon vessels and diluted to $35 \mathrm{ml}$ with distilled-deionized water. Milk powder GBW10017 was used as reference material and treated as described above. Analytical blanks were prepared with each batch of digestion set. All samples were prepared in triplicate run.

Milk treatment for As and Se determination referred to the Chinese National Standard (GB/T 5009.11-2003; GB/T 5009.93-2003). In brief, $10 \mathrm{ml}$
Table 1. Instrumental Conditions for ICP-OES

\begin{tabular}{lcl}
\hline \hline Parameters & Values \\
\hline RF power & $1.20 \mathrm{~kW}$ \\
Argon cooling & 15.0 & $\mathrm{l} / \mathrm{min}$ \\
Argon auxiliary & 1.5 & $\mathrm{l} / \mathrm{min}$ \\
Nebuliser pressure & 240 & $\mathrm{kPa}$ \\
Read delay & 5 & $\mathrm{sec}$ \\
Source equilibration time & 15 & $\mathrm{sec}$ \\
Rinse delay & 30 & $\mathrm{sec}$ \\
Pump rotation rate & 15 & $\mathrm{rpm}$ \\
Washing time & 10 & $\mathrm{sec}$ \\
Number of replicates & 5 & \\
\hline
\end{tabular}

of $6.0 \mathrm{~mol} / \mathrm{l} \mathrm{HCl}$ was added to the digested samples mentioned above. They were slowly heated until color fading. After cooling, $5 \mathrm{ml}$ of $50 \mathrm{~g} / \mathrm{l}$ thiourea and $50 \mathrm{~g} / \mathrm{l}$ ascorbic acid was added for As determination. $2.5 \mathrm{ml}$ of $10 \mathrm{~g} / \mathrm{l} \mathrm{K} 3\left[\mathrm{Fe}(\mathrm{CN})_{6}\right]$ was added for Se determination. Finally, all samples were diluted to $35 \mathrm{ml}$ with distilled-deionized water.

Element Determination — $\mathrm{Ca}$, K, magnesium $(\mathrm{Mg}), \mathrm{P}$, sodium $(\mathrm{Na})$ in samples were determined using ICP-OES. Table 1 shows the parameters optimized for ICP-OES. The emission lines were $\mathrm{Ca}$ $393.336 \mathrm{~nm}, \mathrm{~K} 766.491 \mathrm{~nm}, \mathrm{Mg} 280.270 \mathrm{~nm}, \mathrm{P}$ $213.618 \mathrm{~nm}$, Na $589.592 \mathrm{~nm}$. Fe, Mn (manganese) and $\mathrm{Zn}$ determined by flame-AAS at spectral lines $\lambda=248.3 \mathrm{~nm}$ for $\mathrm{Fe}, \lambda=279.57 \mathrm{~nm}$ for $\mathrm{Mn}$, $\lambda=213.9 \mathrm{~nm}$ for $\mathrm{Zn}$. $\mathrm{Cd}$, chromium $(\mathrm{Cr}), \mathrm{Cu}$, molybdenum (Mo), $\mathrm{Pb}$ by graphite-furnace-AAS at spectral lines $\lambda=228.8 \mathrm{~nm}$ for $\mathrm{Cd}, \lambda=357.9 \mathrm{~nm}$ for $\mathrm{Cr}, \lambda=324.8 \mathrm{~nm}$ for $\mathrm{Cu}, \lambda=313.3 \mathrm{~nm}$ for Mo and $\lambda=283.3 \mathrm{~nm}$ for $\mathrm{Pb}$. As, $\mathrm{Hg}$ and selenium (Se) were determined using AFS at spectral lines $\lambda=193.7 \mathrm{~nm}$ for As, $\lambda=253.7 \mathrm{~nm}$ for $\mathrm{Hg}$, $\lambda=196.0 \mathrm{~nm}$ for Se. $\mathrm{KBH}_{4}$ was used to react with $\mathrm{As}(\mathrm{III})$ and $\mathrm{Se}(\mathrm{IV})$ to produce $\mathrm{AsH} 3$ and H2Se for their determinations in AFS. The instrumental parameters for AAS and AFS come from the softwares present in the machine.

Statistics — Values are expressed as mean \pm S.D. Analysis of variance (ANOVA) was performed to compare the differences among the groups using SPSS 12.0 programme (SPSS Inc., Chicago, IL, U.S.A.). $p<0.05$ was considered significant.

\section{RESULTS AND DISCUSSION}

To evaluate the accuracy and the precision of our analytical method, we analyzed a standard reference material of milk powder. Unfortunately, the 
certified value of $\mathrm{Cd}$ is not given, and only the recommended value of $\mathrm{Hg}$ is given. The determined values and the certified values of the rest 16 elements were very close, suggesting the practicability of our methods (Table 2). In fact, we have success-

Table 2. Comparison between the Determined Values and the Certified Values of the Elements in Standard Reference Material of Milk Powder (Mean \pm S.D., Standard Materials were Determined in Triplication)

\begin{tabular}{lcc}
\hline \hline Element & Determined value & Certified value \\
\hline $\mathrm{As}(\mu \mathrm{g} / \mathrm{kg})$ & $26 \quad \pm 10$ & $31 \pm 7$ \\
$\mathrm{Ca}(\mathrm{g} / \mathrm{kg})$ & $9.1 \pm 0.3$ & $9.4 \pm 0.3$ \\
$\mathrm{Cd}(\mu \mathrm{g} / \mathrm{kg})$ & $1.5 \pm 0.4$ & \\
$\mathrm{Cr}(\mathrm{mg} / \mathrm{kg})$ & $0.28 \pm 0.09$ & $0.39 \pm 0.04$ \\
$\mathrm{Cu}(\mathrm{mg} / \mathrm{kg})$ & $0.42 \pm 0.13$ & $0.51 \pm 0.13$ \\
$\mathrm{Fe}(\mathrm{mg} / \mathrm{kg})$ & $8.1 \pm 0.4$ & $7.8 \pm 1.3$ \\
$\mathrm{Hg}(\mu \mathrm{g} / \mathrm{kg})$ & $\mathrm{ND}$ & $(2.2)$ \\
$\mathrm{K}(\mathrm{g} / \mathrm{kg})$ & $11.3 \pm 0.4$ & $12.5 \pm 0.5$ \\
$\mathrm{Mg}(\mathrm{g} / \mathrm{kg})$ & $1.03 \pm 0.03$ & $0.96 \pm 0.07$ \\
$\mathrm{Mn}(\mathrm{mg} / \mathrm{kg})$ & $0.60 \pm 0.15$ & $0.51 \pm 0.17$ \\
$\mathrm{Mo}(\mathrm{mg} / \mathrm{kg})$ & $0.27 \pm 0.08$ & $0.28 \pm 0.03$ \\
$\mathrm{Na}(\mathrm{g} / \mathrm{kg})$ & $4.3 \pm 0.1$ & $4.7 \pm 0.3$ \\
$\mathrm{P}(\mathrm{g} / \mathrm{kg})$ & $7.0 \pm 0.1$ & $7.6 \pm 0.8$ \\
$\mathrm{~Pb}(\mathrm{mg} / \mathrm{kg})$ & $0.07 \pm 0.01$ & $0.07 \pm 0.02$ \\
$\mathrm{Rb}(\mathrm{mg} / \mathrm{kg})$ & $12.9 \pm 0.4$ & $11.6 \pm 0.7$ \\
$\mathrm{Se}(\mu \mathrm{g} / \mathrm{kg})$ & $88 \quad \pm 11$ & $110 \pm 30$ \\
$\mathrm{Sr}(\mathrm{mg} / \mathrm{kg})$ & $4.5 \pm 1.9$ & $5.3 \pm 0.6$ \\
$\mathrm{Zn}(\mathrm{mg} / \mathrm{kg})$ & $30.4 \pm 2.6$ & $34 \quad \pm 2$ \\
\hline
\end{tabular}

fully analyzed the contents of twenty elements in garlic using ICP-OES, AAS and AFS. ${ }^{14)}$

We determined five macroelements in commercial milks and raw milk (Table 3). The contents of $\mathrm{Ca}$ and $\mathrm{K}$ reached $1000 \mathrm{mg} / \mathrm{kg}$, followed by $\mathrm{P}, \mathrm{Na}$ and $\mathrm{Mg}$. K contents we determined were significantly higher in raw milk than in commercial milks. Because raw milk was collected at one time point, this difference should be interpreted with caution. $\mathrm{Na}$ contents were significantly higher in China 1 than in other three commercial milks and raw milk. However, their contents were in the normal range of the food composition issued by China and Japan (Table 4) ${ }^{15,16)}$ China food composition provides 10 kinds of whole milk for their nutrients and food composition in Japan only shows an average value. It is a common knowledge that milk and milk products are rich in $\mathrm{Ca}$ and other macroelements and its consumption is encouraged. Chinese Food Guide recommends a daily intake of $300 \mathrm{~g}$ of milk and milk products. ${ }^{17)}$ The recommendation in Japanese Dietary Guidelines is 2 servings of milk products and alternatives $(1$ serving $=100 \mathrm{ml}$ of milk or yogurt). ${ }^{18)}$

Nine microelements were determined in the present study. In generally, the microelements in milk decreased in the order of $\mathrm{Zn}>\mathrm{Fe}>\mathrm{Mn}, \mathrm{Cu}$, $\mathrm{Mo}, \mathrm{Cr}>\mathrm{Se}>\mathrm{Sr}>\mathrm{Rb}$ (Table 3). Zn contents

Table 3. The Determined Values of the Element Contents in Different Kinds of Milks (Mean \pm S.D., $n=8$ in Triplication for Each Sample)

\begin{tabular}{|c|c|c|c|c|c|}
\hline Element & China 1 & China 2 & Japan 1 & Japan 2 & Raw milk \\
\hline \multicolumn{6}{|l|}{ Macroelement } \\
\hline $\mathrm{Ca}(\mathrm{mg} / \mathrm{kg})$ & 1006 & \pm 29 & 1011 & 1053 & 1041 \\
\hline $\mathrm{K}(\mathrm{mg} / \mathrm{kg})$ & $\pm 43^{a)}$ & $\pm 33^{a)}$ & $\pm 10^{a)}$ & $\pm 46^{a)}$ & 1117 \\
\hline $\mathrm{Mg}(\mathrm{mg} / \mathrm{kg})$ & \pm 8 & \pm 4 & \pm 5 & \pm 9 & \pm 16 \\
\hline $\mathrm{Na}(\mathrm{mg} / \mathrm{kg})$ & \pm 83 & $\pm 22^{b)}$ & $\pm 24^{b)}$ & $\pm 31^{b)}$ & $\pm 96^{b)}$ \\
\hline $\mathrm{P}(\mathrm{mg} / \mathrm{kg})$ & \pm 59 & \pm 35 & \pm 18 & \pm 80 & \pm 61 \\
\hline \multicolumn{6}{|l|}{ Microelement } \\
\hline $\mathrm{Cr}(\mathrm{mg} / \mathrm{kg})$ & $0.17 \pm 0.05$ & $0.16 \pm 0.04$ & $0.09 \pm 0.03^{b, c)}$ & $0.06 \pm 0.02^{b, c)}$ & $0.14 \pm 0.03$ \\
\hline $\mathrm{Cu}(\mathrm{mg} / \mathrm{kg})$ & $0.17 \pm 0.06$ & $0.28 \pm 0.06^{a)}$ & $0.23 \pm 0.02$ & $0.33 \pm 0.05^{a)}$ & $0.17 \pm 0.08$ \\
\hline $\mathrm{Fe}(\mathrm{mg} / \mathrm{kg})$ & $2.21 \pm 0.56$ & $2.44 \pm 0.59$ & $1.51 \pm 0.12$ & $1.63 \pm 0.16$ & $1.93 \pm 0.96$ \\
\hline $\mathrm{Mn}(\mathrm{mg} / \mathrm{kg})$ & $0.38 \pm 0.07$ & $0.36 \pm 0.05$ & $0.18 \pm 0.06^{b, c)}$ & $0.19 \pm 0.02^{b, c)}$ & $0.20 \pm 0.01^{b, c)}$ \\
\hline Mo $(\mathrm{mg} / \mathrm{kg})$ & $0.18 \pm 0.07$ & $0.19 \pm 0.06$ & $0.19 \pm 0.04$ & $0.13 \pm 0.03$ & $0.13 \pm 0.05$ \\
\hline $\mathrm{Rb}(\mu \mathrm{g} / \mathrm{kg})$ & $1.48 \pm 0.16$ & $1.84 \pm 0.12$ & $1.70 \pm 0.32$ & $1.29 \pm 0.11$ & $1.43 \pm 0.39$ \\
\hline $\mathrm{Se}(\mu \mathrm{g} / \mathrm{kg})$ & $45.77 \pm 18.79$ & $67.15 \pm 23.07$ & $51.91 \pm 9.33$ & $66.44 \pm 18.59$ & $42.14 \pm 18.50$ \\
\hline $\mathrm{Sr}(\mu \mathrm{g} / \mathrm{kg})$ & $5.66 \pm 0.23$ & $5.45 \pm 0.25$ & $4.94 \pm 0.33$ & $4.63 \pm 0.29$ & $5.06 \pm 1.12$ \\
\hline $\mathrm{Zn}(\mathrm{mg} / \mathrm{kg})$ & $3.65 \pm 1.79$ & $3.62 \pm 1.66$ & $2.72 \pm 0.61$ & $3.04 \pm 0.46$ & $2.38 \pm 0.50$ \\
\hline \multicolumn{6}{|c|}{ Heavy metal (Toxic metal) } \\
\hline As $(\mu \mathrm{g} / \mathrm{kg})$ & ND & ND & ND & ND & ND \\
\hline $\mathrm{Cd}(\mu \mathrm{g} / \mathrm{kg})$ & $4.53 \pm 3.01$ & $4.25 \pm 3.03$ & $1.13 \pm 0.64$ & $2.01 \pm 1.06$ & $4.19 \pm 3.80$ \\
\hline $\mathrm{Hg}(\mu \mathrm{g} / \mathrm{kg})$ & ND & ND & ND & ND & ND \\
\hline $\mathrm{Pb}(\mu \mathrm{g} / \mathrm{kg})$ & $35.01 \pm 8.63$ & $32.97 \pm 11.24$ & $11.98 \pm 3.27^{a, b, c)}$ & $12.95 \pm 2.94^{a, b, c)}$ & $28.15 \pm 11.23$ \\
\hline
\end{tabular}

a) Significantly different from Raw milk. $b$ ) Significantly different from China 1. c) Significantly different from China 2. 
Table 4. Mineral Contents in Liquid Milk

\begin{tabular}{lcc}
\hline \hline & $\begin{array}{l}\text { From The } \\
\text { Composition of } \\
\text { Chinese foods }\end{array}$ & $\begin{array}{l}\text { From Standard Tables } \\
\text { of Food Composition } \\
\text { in Japan }\end{array}$ \\
\hline $\mathrm{Ca}(\mathrm{mg} / \mathrm{kg})$ & $820-1130$ & 1100 \\
$\mathrm{Cu}(\mathrm{mg} / \mathrm{kg})$ & $\mathrm{Tr}-0.2$ & 0.1 \\
$\mathrm{Fe}(\mathrm{mg} / \mathrm{kg})$ & $1-6$ & 0.2 \\
$\mathrm{~K}(\mathrm{mg} / \mathrm{kg})$ & $1320-3480$ & 1500 \\
$\mathrm{Mg}(\mathrm{mg} / \mathrm{kg})$ & $80-120$ & 100 \\
$\mathrm{Mn}(\mathrm{mg} / \mathrm{kg})$ & $\mathrm{Tr}-0.2$ & 0.2 \\
$\mathrm{Na}(\mathrm{mg} / \mathrm{kg})$ & $248-2921$ & 410 \\
$\mathrm{P}(\mathrm{mg} / \mathrm{kg})$ & $590-1030$ & 930 \\
$\mathrm{Zn}(\mathrm{mg} / \mathrm{kg})$ & $2.5-6.7$ & 4.0 \\
\hline
\end{tabular}

in two Chinese commercial milks varied between $1.34-5.22 \mathrm{mg} / \mathrm{kg}(3.65 \pm 1.79 \mathrm{mg} / \mathrm{kg})$ and 1.38 $4.96 \mathrm{mg} / \mathrm{kg} \quad(3.62 \pm 1.66 \mathrm{mg} / \mathrm{kg}) ;$ however, these ranges were $2.23-3.56 \mathrm{mg} / \mathrm{kg}(2.72 \pm 0.61 \mathrm{mg} / \mathrm{kg})$ and $2.85-3.73 \mathrm{mg} / \mathrm{kg}(3.04 \pm 0.46 \mathrm{mg} / \mathrm{kg})$ in two Japanese commercial milks. Relatively high content in Chinese commercial milks with a large variation was also observed in $\mathrm{Fe}$ contents. $\mathrm{Zn}$ and $\mathrm{Fe}$ can transfer to food from the tools and machines used in the milk collection and production. We speculated that it was caused by the differences of technology and quality control between two countries. Mn contents were significantly higher in Chinese commercial milks $(0.38 \pm 0.07 \mathrm{mg} / \mathrm{kg}, 0.36 \pm 0.05 \mathrm{mg} / \mathrm{kg})$ than in Japanese commercial milks $(0.18 \pm 0.06 \mathrm{mg} / \mathrm{kg}$, $0.19 \pm 0.02 \mathrm{mg} / \mathrm{kg}$ ). Since $\mathrm{Mn}$ content in raw milk was $0.20 \pm 0.01 \mathrm{mg} / \mathrm{kg}$, the process of milk production seems to contribute to the high Mn contents in Chinese commercial milks. $\mathrm{Cu}$ contents were slightly higher in the four determined commercial milk when comparing with the food composition (Table 4); however, their contents were obviously lower than the milk sample from special area. Simsek et al. found $\mathrm{Cu}$ in milk was as high as $0.96(0.77-1.20) \mathrm{mg} / \mathrm{kg}$ in Industrial region. ${ }^{7)}$ Thus, $\mathrm{Cu}$ content in milk is likely to be strongly influenced by environment. $\mathrm{Cr}$ contents were significantly higher in Chinese commercial milks $(0.17 \pm 0.05 \mathrm{mg} / \mathrm{kg}, 0.16 \pm 0.04 \mathrm{mg} / \mathrm{kg})$ than in Japanese commercial milks $(0.09 \pm 0.03 \mathrm{mg} / \mathrm{kg}$, $0.06 \pm 0.02 \mathrm{mg} / \mathrm{kg}$ ). Although $\mathrm{Cr}$ and other microelments are essential to maintain the metabolic systems of human body, they can lead to poisoning at higher level. Chinese commercial milks we determined are safe for drinker in this issue because the tolerance limit of $\mathrm{Cr}$ in milk is $0.3 \mathrm{mg} / \mathrm{kg}$ (GB/T 1461-94). We also determined Mo, Rb, Se and $\mathrm{Sr}$ in milks, whose contents are in $\mu \mathrm{g} / \mathrm{kg}$ level (Table 3). These elements have a great impact on human health. For example, Se has a relatively narrow range of safety, and large amounts can lead to hair lose, brittle nails and other side effects. ${ }^{19)}$ However, there are no reports about these elements in milk. The contents of these elements also have not included in the food composition table. Thus, our analysis provided useful basic data for the further research.

As, $\mathrm{Cd}, \mathrm{Hg}$ and $\mathrm{Pb}$ in milk have drawn much public attention due to the food safety issues and potential healthy risk. No As and $\mathrm{Hg}$ were detected in the collected milk samples. The detection limits of $\mathrm{As}$ and $\mathrm{Hg}$ in our study were $0.06 \mu \mathrm{g} / \mathrm{kg}$ and $0.015 \mu \mathrm{g} / \mathrm{kg}$. Our results are in agreement with other reports. For example, As and $\mathrm{Hg}$ contents in milk were less than $10 \mu \mathrm{g} / 1$ in Spain. ${ }^{20)}$ $\mathrm{Hg}$ even cannot be determined in the milk from heavy traffic region and industrial region. ${ }^{7)} \mathrm{Cd}$ is considered to be the most important contaminant in modern times. $\mathrm{Cd}$ contents in Chinese commercial milks $(4.53 \pm 3.01 \mu \mathrm{g} / \mathrm{kg}, 4.25 \pm 3.03 \mu \mathrm{g} / \mathrm{kg})$ are 2-3 times more than Japanese commercial milk $(1.13 \pm 0.64 \mu \mathrm{g} / \mathrm{kg}, 2.01 \pm 1.06 \mu \mathrm{g} / \mathrm{kg})$. Since $\mathrm{Cd}$ content in raw milk from Inner Mongolia $(4.19 \pm 3.80 \mu \mathrm{g} / \mathrm{kg})$ was similar with Chinese commercial milks, the high content of $\mathrm{Cd}$ is not likely from the process of milk production. Through 3 years' monitor, Vidovic found a decrease of Cd $(93 \%)$ in atmospheric deposits, followed by a decrease in soil $(30 \%)$, in cattle feeds $(17 \%)$ and in milk $(13 \%),{ }^{8}$ suggesting an atmospheric deposits-soil-cattle feed-milk chain. $\mathrm{Pb}$ is a heavy metal of wide occupational and environmental concern. $\mathrm{Pb}$ contents in Chinese commercial milks $(35.01 \pm 8.63 \mu \mathrm{g} / \mathrm{kg}, 32.97 \pm 11.24 \mu \mathrm{g} / \mathrm{kg})$ and raw milk $(28.15 \pm 11.23 \mu \mathrm{g} / \mathrm{kg})$ were significantly higher than in Japanese commercial milks $(11.98 \pm 3.27 \mu \mathrm{g} / \mathrm{kg}, 12.95 \pm 2.94 \mu \mathrm{g} / \mathrm{kg})$. The tolerance limit of $\mathrm{Pb}$ in milk is $50 \mu \mathrm{g} / \mathrm{kg}$ according to GB/T 14935-94. One of samples in China 1 and China 2 exceed this limit. In Japan, $\mathrm{Pb}$ concentration in atmospheric air was $15-81 \mathrm{ng} / \mathrm{m}^{3},{ }^{21}$ ) however, it was as high as $90-2800 \mathrm{ng} / \mathrm{m}^{3}$ in China. ${ }^{22}$ ) Therefore, environmental pollution leads to high $\mathrm{Pb}$ content in milk through atmospheric deposits-soilcattle feed-milk chain. On the other hand, the pollution from milk process and milk container should not be ignored. Food Safety Committee of Japan has set $1 \mathrm{ppm}$ as the limit of heavy metal in the solution when milk container is extracted by $4 \%$ acetic 
acid. ${ }^{23)}$

In conclusion, milk contains considerable amounts of minerals, which are beneficial to human health. Milk is not the main source of heavy metal intake from foodstuffs ${ }^{8)}$ and these commercial milks are safe for drinker according to the current standards. However, some microelements and heavy metals in Chinese commercial milk are high when compared with Japanese commercial milk. It suggests that the technology and quality control for milk process should be improved and environmental pollution should be controlled.

Acknowledgements This work was supported in part by grants from National Natural Science Foundation of China (30771808), and from Medical Development Foundation of Soochow University (EE126712). Li-Qiang Qin and Xiao-Ping Wang contributed equally to the work. Authors are grateful to the contributions of Xiang-Liu Su, Yi-Ming Wu and Xiao-Dong Pan.

\section{REFERENCES}

1) Lampert, L. M. (1984) The Minerals and water in milk. In Modern Dairy Products, Chemical Publishing Co., New York, pp. 57-70.

2) International Dairy Federation (2007) The world dairy situation 2007, Bulletin of the International Dairy Federation, 423/2007, 76-84.

3) Gundacker, C., Pietschnig, B., Wittmann, K. J., Lischka, A., Salzer, H., Hohenauer, L. and Schuster, E. (2002) Lead and Mercury in Breast Milk. Pediatrics, 110, 873-878.

4) Honda, R., Tawara, K., Nishijo, M., Nakagawa, H., Tanebe, K. and Saito, S. (2003) Cadmium exposure and trace elements in human breast milk. Toxicology, 186, 255-259.

5) Yamawaki, N., Yamada, M., Kanno, T., Kojima, T., Kaneko, T. and Yonekubo, A. (2005) Macronutrient, mineral and trace element composition of breast milk from Japanese women. J. Trace Elem. Med. Biol., 19, 171-181.

6) Abdulrazzaq, Y. M., Osman, N., Nagelkerke, N., Kosanovic, M. and Adem, A. (2008) Trace element composition of plasma and breast milk of wellnourished women. J. Environ. Sci. Health A Tox. Hazard. Subst. Environ. Eng., 43, 329-334.

7) Simsek, O., Gültekin, R., Öksüz, O. and Kurultay, S. (2000) The effect of environmental pollution on the heavy metal content of raw milk. Nahrung, 44,
S360-S363.

8) Vidovic, M., Sadibasic, A., Cupic, S. and Lausevic, M. (2005) $\mathrm{Cd}$ and $\mathrm{Zn}$ in atmospheric deposit, soil, wheat, and milk. Environ. Res., 97, 26-31.

9) Ramamurthy, N. and Thillaivelavan, K. (2005) Determination of trace elements in dairy milk collected from the environment of coal-fired power plant. Journal of Environmental Science and Engineering, 47, 53-58.

10) Zheng, N., Wang, Q., Zhang, X., Zheng, D., Zhang, Z. and Zhang, S. (2007) Population health risk due to dietary intake of heavy metals in the industrial area of Huludao city, China. Sci. Total Environ., 387, 96-104.

11) Mao, Y. Z., Chen, Y. and Yin, M. J. (1999) The analysis of elements in whole-fat milk. Literature Information of Prevenive Medicine, 5, 377 (in Chinese).

12) Watanabe, T., Watanabe, J. and Yito, W. (1986) The survey of heavy metals in fish, milk and vegetables. Kanagawa Prefectural Institute of Public HealthAnnual Report, 35, 65 (in Japanese).

13) Ayar, A., Sert, D. and Akin, N. (2008) The trace metal levels in milk and dairy products consumed in middle Anatolia-Turkey. Environ. Monit. Assess., in press.

14) Wang, X. P. and Xiang, S. L. (2006) Studies on the contents of twenty elements in different parts of garlic by using ICP-OES, AAS and AFS combined with microwave decomposition method. Spectroscopy \& Spectral Analysis, 26, 1907-1911 (in Chinese).

15) Yang, Y. X. (2004) China Food Composition, Book 2, Peking University Medical Press, Beijing.

16) Kagawa, Y. (2007) Standard Tables of Food Composition in Japan, 5th Edition, Kagawa Nutrition University Publishing Division, Saitama.

17) Chinese Nutrition Society (2007) Chinese Food Guide, Xizang People Press, Lasha.

18) Ministry of Agriculture, Forestry and Fisheries (2005) Japanese Dietary Guidelines. http://www. maff.go.jp/j/balance_guide/index.html

19) Vinceti, M., Wei, E. T., Malagoli, C., Bergomi, M. and Vivoli, G. (2001) Adverse health effects of selenium in humans. Rev. Environ. Health, 16, 233-251.

20) Liobet, J. M., Falco, G., Casas, C., Teixidó, A. and Domingo, J. L. (2003) Concentration of arsenic, cadmium, mercury, and lead in common foods and estimated daily intake by children, adolescents, adults, and seniors of Catalonia, Spain. $J$. Agric. Food Chem., 51, 838-842.

21) Environment Agency of Japanese Government (1997) Air pollution in Japan, 1980 and 1996, Gyosei Publishers, Tokyo.

22) Zhang, Z. W., Qu, J. B. and Ikeda, M. (1998) Lead 
and cadmium levels in the atmosphere in Mainland China: a review. J. Occup. Health, 40, 257-263.

23) Ministry of Health, Labour and Welfare (2007) http://www.mhlw.go.jp/shingi/2007/03/dl/s0312-

12c.pdf 